\title{
NEK3 wt Allele
}

National Cancer Institute

\section{Source}

National Cancer Institute. NEK3 wt Allele. NCI Thesaurus. Code C104844.

Human NEK3 wild-type allele is located in the vicinity of $13 q 14.13$ and is approximately 27

$\mathrm{kb}$ in length. This allele, which encodes serine/threonine-protein kinase Nek3 protein, is involved in neuronal morphogenesis and polarity. 